\title{
The impact of multiple drug therapy on leprosy disabilities*
}

\author{
MERLIN L. WILLCOX, \\ Keble College, Oxford OX1, UK
}

Accepted for publication 22 September 1997

\begin{abstract}
Summary In an overview of controlled trials, it is shown that bactericidal drugs increase the short-term risk of Type I reactions, but prevent the long-term development of new impairments caused by bacterial proliferation. Clinical experience suggests that the clofazimine component of multiple drug therapy (MDT) has reduced the incidence of Type II reactions or erythema nodosum leprosum (ENL). The principal impact of MDT, compared with monotherapy, has been to reduce the duration of active disease, thus preventing the deterioration of disability scores. Reduction of population disability rates is mainly achieved by earlier detection and treatment. MDT has a number of indirect benefits such as improved compliance, decreased cost, and increased motivation and availability of leprosy workers. However, MDT must be supplemented by other measures to prevent and treat disabilities.
\end{abstract}

\section{Introduction}

In 1994, there were an estimated $2 \cdot 4$ million active cases of leprosy in the world ${ }^{1}$ and $2-3$ million people had deformities (that is, visible physical changes) caused by this disease. Unlike the closely-related disease of tuberculosis, leprosy is rarely fatal and not highly infectious. Yet the disabilities it causes can ruin lives - not only because they may prevent patients from doing their normal jobs, but also because of the social stigma attached to them. ${ }^{2,3}$ A recent survey in India ${ }^{3}$ found that up to $46 \%$ of deformed patients may be rejected by their families.

Disabilities are part of a continuum of the effects of leprosy, which can be divided into three tiers: ${ }^{4}$ impairment, disability and handicap. The disease damages nerves, producing impairments in sensory and motor function. These may cause disability directly-by making certain actions more difficult-or indirectly, by allowing injuries to occur unnoticed. Affected individuals may become handicapped in society when they can no longer fulfil their normal roles.

Combinations of antibiotics were first used to treat leprosy in $1971,{ }^{5}$ but did not become widespread until after 1982, when the World Health Organization introduced standardized regimes: 6 months for paucibacillary patients, and 24 months for multibacillary cases.

* First Prize, Lepra Essay, 1995. 
This article will review the impact of multiple drug therapy (MDT) on leprosy disabilities at two different levels: therapeutic (the impact on different types of impairment, which cause disabilities), and preventive (the impact on individuals with different types of leprosy at risk of becoming disabled). The search for relevant papers was conducted systematically using the MEDLINE database, and the references of these papers were also searched for other relevant publications.

\section{The therapeutic impact of multidrug therapy on different types of impairment}

Leprosy disabilities result from impairments produced by disease. The pattern of disease determines which impairments develop and what treatment is required. In lepromatous leprosy, impairments result from bacterial proliferation, whilst in tuberculoid disease, the immune response damages nerves.

To review the impact of MDT, it is most useful to consider its effect on the two main processes causing impairments: neuritis and local proliferation. Neuritis may produce permanent motor impairments (often at a site remote from the actual lesion), and sensory impairments, which allow secondary damage of tissues to occur unnoticed. Local bacterial proliferation causes specific deformities in particular anatomical sites.

\section{NEURITIS}

Neuritis is usually asymptomatic and nerve function may gradually deteriorate without the patient noticing. ${ }^{6-8}$ This may occur in spite of chemotherapy, perhaps due to gradually increasing pressure on the nerve. ${ }^{9}$ Paradoxically, because it goes unnoticed, silent neuritis may cause at least as many impairments as the more severe (acute) neuritis, which presents with nerve pain and/or sudden loss of function.

While antileprosy therapy is required to kill the causative organisms, it may increase the risk of neuritis, ${ }^{10}$ for which additional treatment is needed. If treated promptly with steroids, many patients recover, or at least their nerve damage is limited. ${ }^{8,10}$ This has prompted leprosy workers to advocate regular screening of nerve function in their patients. ${ }^{6,8}$ The fact that nerve damage can be reversed or limited is not appreciated by all field staff; when it is, treatment and screening are much improved. ${ }^{6,8}$

Type I Reactions (TIRs), episodes of increased inflammatory activity in skin lesions and/or nerves, ${ }^{11}$ are one cause of neuritis. They may result from an increase in the cell-mediated immune response and the formation of granulomata. ${ }^{12}$ Inflammation in the nerves causes pain, but the most important consequence are motor impairments and disability. TIRs also increase the risk of arthritis. ${ }^{13}$

The reported incidence of TIR varies widely from study to study. The comprehensive review by Lienhardt and Fine ${ }^{11}$ found that TIRs occur commonly during and after chemotherapy. Indeed, for patients not in TIR at the time of diagnosis, the greatest risk of TIR is in the first 6-12 months of treatment. The lack of clinical trials with long-term followup before the introduction of MDT makes it difficult to compare the risk of TIR under monotherapy and MDT. A retrospective study is quoted from Malawi which found a lower risk of TIR with MDT than with DDS monotherapy.

Table 1 summarizes the randomized controlled trials which quote incidence of TIR. In paucibacillary patients, Orege et al. ${ }^{14}$ found no difference between WHO and modified regimens. Groenen et al. ${ }^{15}$ found a much higher incidence of TIR in rifampicin monotherapy (B) 
than in a modified MDT regimen (A) or a single dose of rifampicin (U). The allocation of patients was not entirely random - those not prepared to come to the centre weekly were automatically given MDT (A) - but this is unlikely to account for the very large difference observed.

All the other studies refer to multibacillary patients. Groenen et al. ${ }^{15}$ found a significantly lower incidence of TIR with the WHO regimen than with alternative high dose rifampicin regimens. Singh et al $^{22}$ also found a greater incidence of TIR and neuritis in a modified WHO regimen with high dose rifampicin, but the difference was not statistically significant due to the small numbers studied. Thomas et al. ${ }^{21}$ found no difference between a regimen containing high dose rifampicin and another containing no rifampicin. Interactions with other drugs make these results hard to interpret; it seems that rifampicin may increase the risk of TIR in certain drug combinations but not in others.

Groenen $e t a l .{ }^{15}$ found that clofazimine seemed to reduce the frequency, duration and severity of TIR as compared to dapsone. However, their groups were not randomised: patients who had taken DDS monotherapy for more than 5 years received clofazimine, and those who had not continued with DDS. The authors also found that previously untreated patients were more at risk of TIRs, so this could explain the differences between their groups. Jamet et al. ${ }^{16}$ found that clofazimine monotherapy did not suppress TIRs, and that high doses could increase their incidence.

The role of dapsone is unclear. Dietrich et $a l^{17}$ found no difference in the incidence of TIRs between dapsone monotherapy and two MDT regimens. Barnetson et al. ${ }^{25}$ found that patients receiving low dose DDS monotherapy ( $5 \mathrm{mg}$ od) were more at risk of TIR than those receiving higher doses (50 $\mathrm{mg}$ od). They observe that DDS must have an anti-inflammatory effect at higher doses since $1 \mathrm{mg}$ daily is the minimal dose for antibacterial activity.

Any antibacterial chemotherapy could release antigens which could stimulate the cellmediated immune response (CMI). A histological study of patients undergoing MDT found evidence of immune activation even in patients without a TIR. ${ }^{26}$ More potent chemotherapy such as rifampicin may carry a greater risk, but other drugs such as DDS and clofazimine may help to diminish this risk. In summary, MDT probably increases the incidence of TIR in comparison to no treatment, but may or may not do so in comparison to dapsone monotherapy.

Type II reactions (erythema nodosum leprosum (ENL)) following MDT have been studied by several researchers. ENL is thought to be an immune-complex reaction; it causes not only neuritis but also systemic effects, such as widespread subcutaneous erythematous nodules, fever and iritis. ${ }^{12}$ It rarely results in permanent loss of nerve function, but repeated attacks occasionally cause deformities in the hands such as 'swan-neck', 'twisted fingers' or 'nonparalytic clawing'. ${ }^{10}$ ENL may also cause acute-onset arthritis, distinct from that mentioned see p. 356. This variety usually only causes temporary disability; nevertheless, extended episodes have been reported. ${ }^{27,28}$ Atkin's survey ${ }^{28}$ found $22 \%$ of patients had ENL-related arthritis, of whom only one (8\%) had bone erosions.

Table 2 summarizes the randomized controlled trials (RCTs) of different chemotherapy regimes for MB leprosy, together with the percentage of patients reported to have suffered at least one ENL reaction during the follow-up. Cellona et al. ${ }^{29}$ quoted a percentage for each year rather than an overall figure; the maximum for each year is reported in the table. Unfortunately percentages are not comparable between studies because of the varying follow-up periods, and because there is no indication of the severity of reactions. However, comparisons between groups within any study should be valid.

Starting any chemotherapy increases the risk of ENL, compared to no treatment. 
Table 1. Randomised-Controlled Trials of MDT for PB and MB leprosy and incidence of Type I reactions

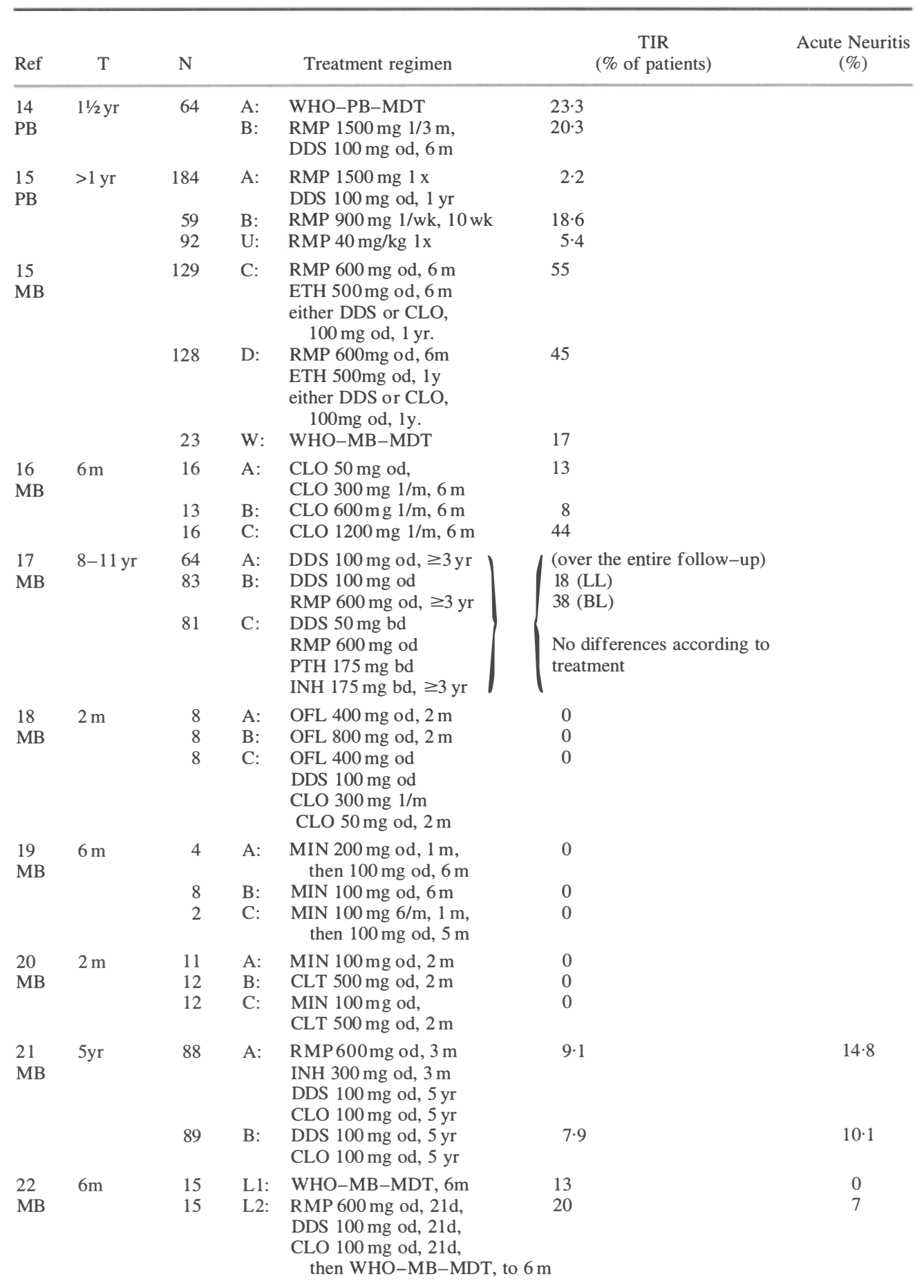


Table 1. (Continued)

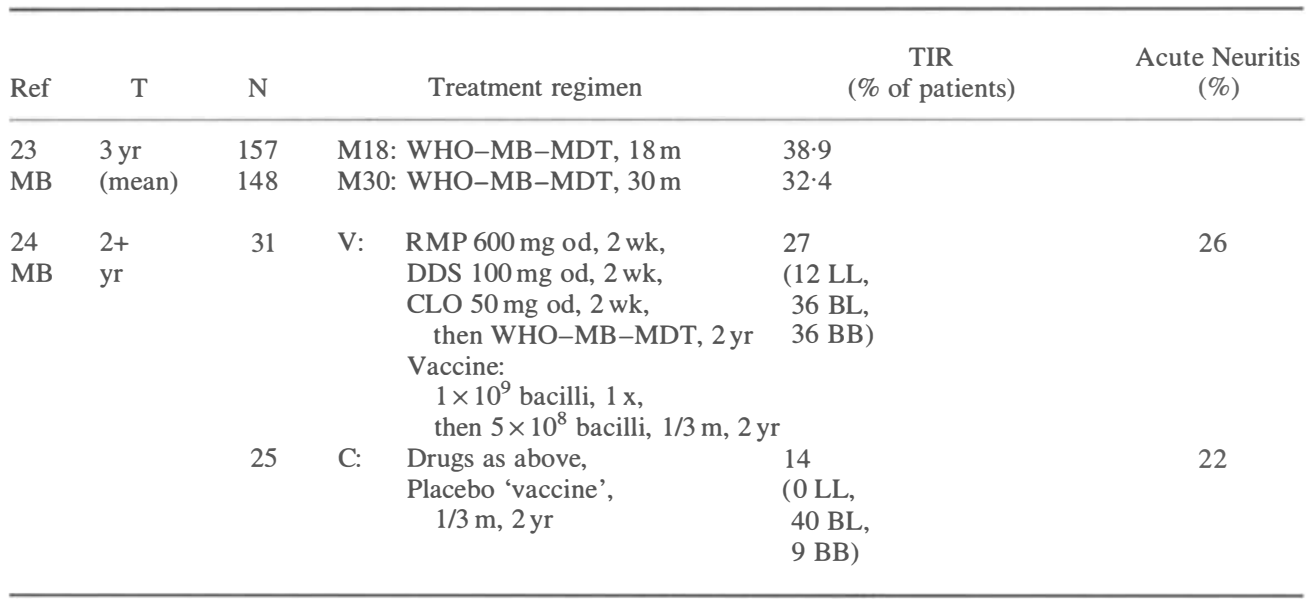

Abbreviations:

$\mathrm{T}$, length of follow-up period; $\mathrm{N}$, number of subjects.

CLO, clofazimine; CLT, clarithromycin; DDS, dapsone; ETH, ethionamide; INH, isoniazid; MIN, minocycline; OFL, ofloxacin; PTH, prothionamide; RMP, rifampicin; THI, thiacetazone.

WHO-PB-MDT, WHO regimen for PB leprosy (RMP $600 \mathrm{mg} \mathrm{1/m}$, DDS $100 \mathrm{mg}$ od, $6 \mathrm{~m}$ ).

WHO-MB-MDT, WHO regimen for MB leprosy (RMP $600 \mathrm{mg} \mathrm{1/m,} \mathrm{CLO} 300 \mathrm{mg} \mathrm{1/m}$, CLO $50 \mathrm{mg}$ od, DDS $100 \mathrm{mg}$ od, $2 \mathrm{yr}$ ).

od, once daily; bd, twice daily; $1 \mathrm{x}$, single dose; $1 / \mathrm{m}$, once a month; $1 / 3 \mathrm{~m}$, once every three months.

d, day(s); wk, week(s); m, month(s); yr, year(s).

Becx-Bleumink ${ }^{32}$ reports a substantial rise in the number of ENL reactions during the first year of MDT, as compared to the time of diagnosis. Bwire \& Kawuma ${ }^{33}$ in a 5 -year study of 2317 leprosy patients in Uganda, found that 17 of 18 patients with ENL were on MDT. However, the incidence of ENL has decreased since MDT replaced monotherapy. ENL used to occur in $50 \%$ of LL patients and $30 \%$ of BL patients. ${ }^{34}$ Since the introduction of MDT, ENL has become less common, ${ }^{35,36}$ occurring in only about $20 \%$ and $10 \%$ of LL and BL patients respectively (Lockwood D.N.J., personal communication).

It is a pity that the only trial comparing monotherapy with MDT $^{17}$ did not use WHO MDT; the MDT regimen used contained larger doses of rifampicin and did not include clofazimine. Not surprisingly, there was no significant difference in the incidence of ENL between groups. Large doses of rifampicin may increase the risk of ENL, while clofazimine may decrease it.

Clofazimine is known to be anti-inflammatory as well as bactericidal. ${ }^{6,37,37 a}$ Treatment of ENL by clofazimine has been reported by Burte $e t a l .{ }^{37}$ All the symptoms of neuritis, with the notable exception of anaesthesia, showed complete recovery in 15 of their 20 patients treated for ENL with clofazimine, and the severity of the reaction was reduced in the five others. Helmy et al $^{37 \mathrm{a}}$ found that clofazimine was significantly better than placebo for the treatment of ENL in a small double-blind randomized crossover trial.

Clofazimine is believed to be responsible for the decreased risk of ENL observed since the introduction of WHO-MDT (Lockwood D.N.J., personal communication). Unfortunately, no trials of sufficient quality have been conducted to prove this. Cellona et al. ${ }^{29}$ found that clofazimine suppresses ENL: patients on their regimens IIA, IIB and IIC, which included 
Table 2. Randomized-controlled Trials of MDT for MB leprosy and incidence of ENL reactions [for key to abbreviations, see Table 1]

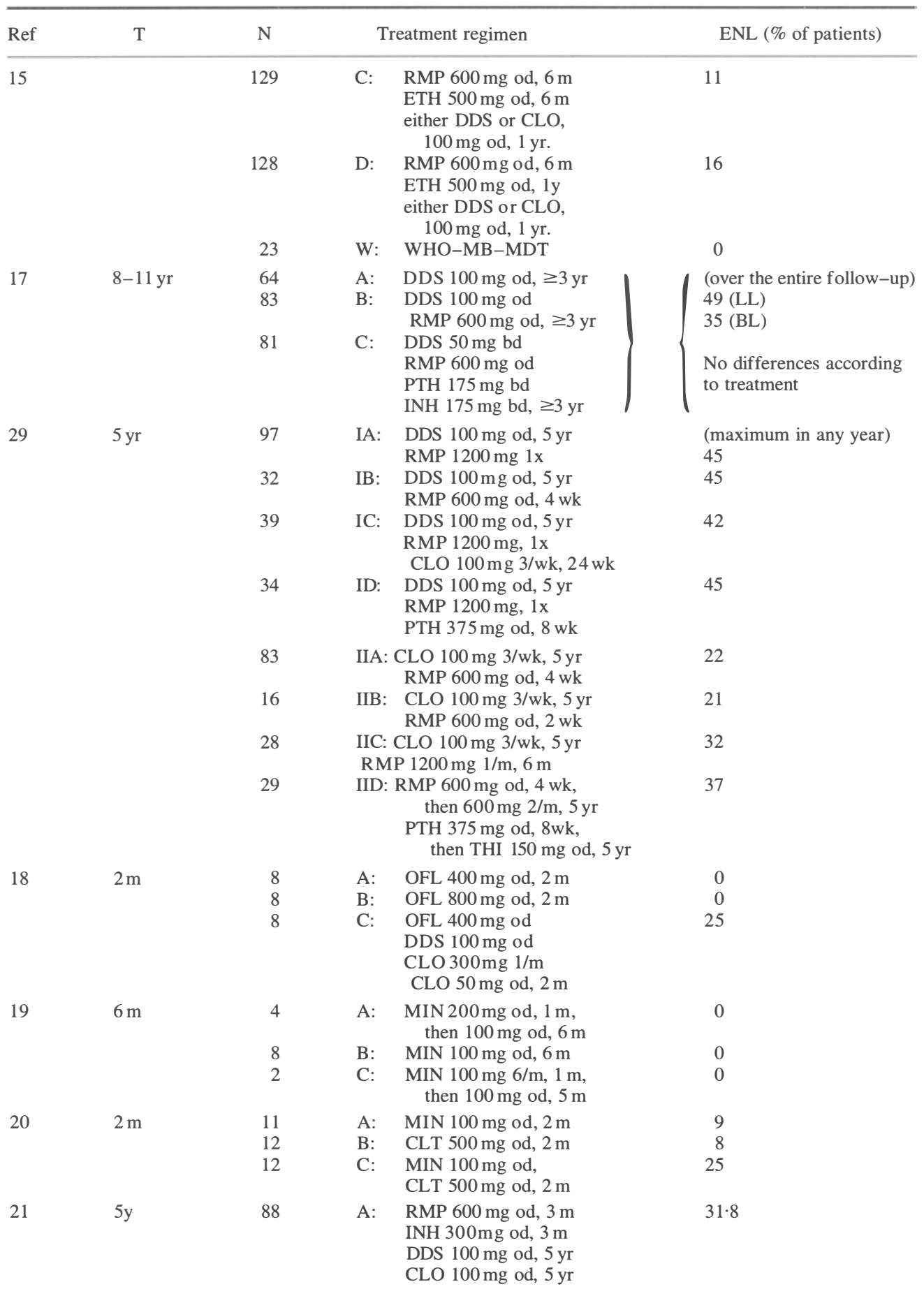


Table 2. (Continued)

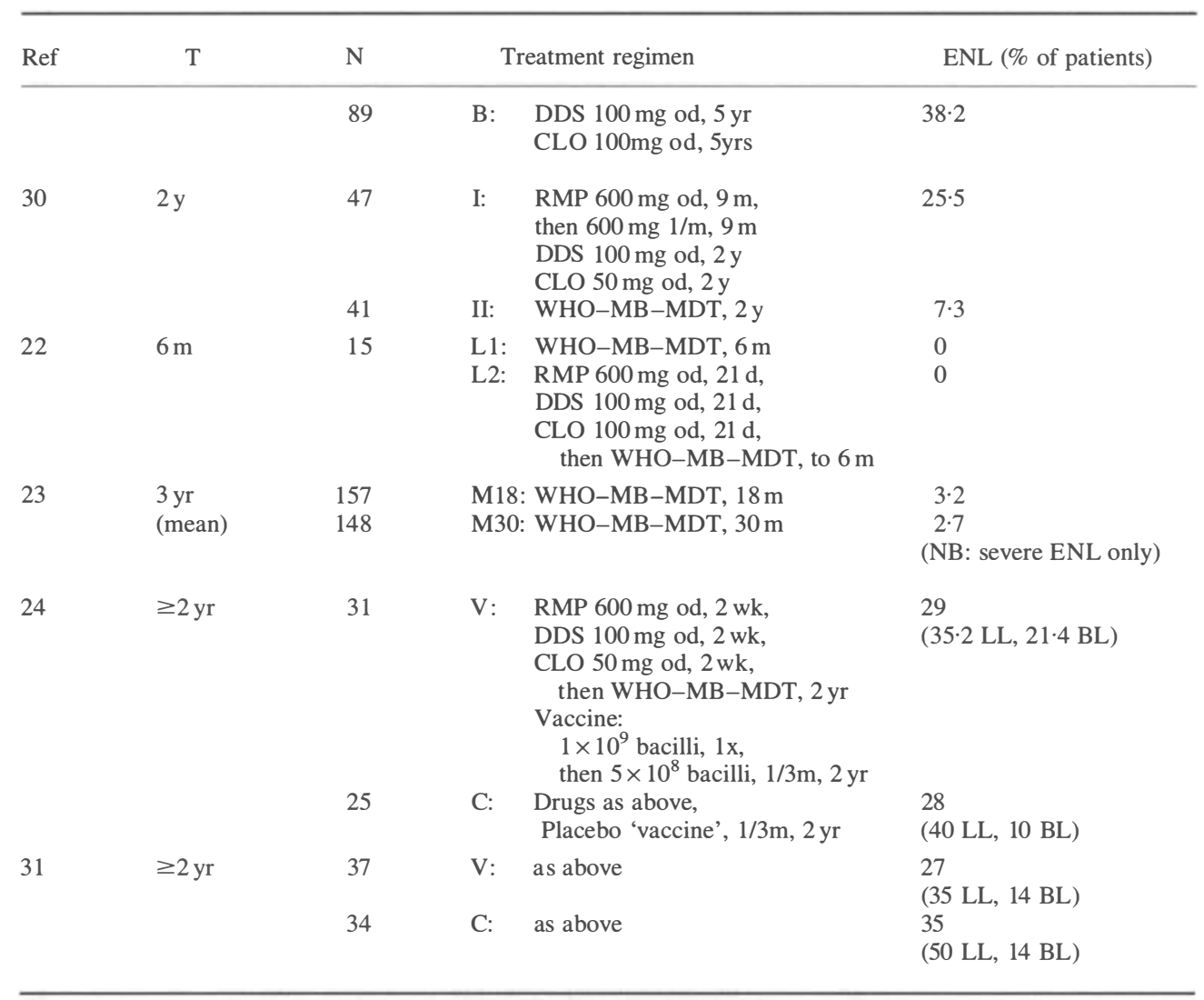

regular clofazimine for 5 years, had a much lower incidence of ENL than those on other regimens. However, this trial was not truly randomized: subjects in group I were all newly-diagnosed patients whereas those in group II were all relapsed patients previously treated with dapsone monotherapy. Groenen et al. ${ }^{15}$ found no difference in incidence of ENL, whether clofazimine or DDS was used as the third drug; but as discussed above, this trial was not randomized either. Furthermore, the effect of clofazimine could have been masked by large daily doses of rifampicin and/or ethionamide. Regimens containing these had a higher incidence of ENL than the WHO regimen, although a much smaller number of patients took the WHO regimen. Ji et al. ${ }^{18}$ found more ENL in the regimen containing clofazimine and dapsone than in the regimens containing ofloxacin alone, but the number of subjects in their trial was too small for chance differences to be ruled out.

Rifampicin, known to be potently bactericidal, could increase the risk of ENL because of the rapid breakdown of bacilli and release of antigens into the circulation, which could then form the immune complexes believed to be involved in ENL. ${ }^{12}$ This hypothesis is supported by Jadhav et al., ${ }^{30}$ but not by Thomas et al. ${ }^{21}$ or Singh et al. ${ }^{22}$ The trial by Jadhav et al. ${ }^{30}$ seems to be the best test of high dose rifampicin: it found a much higher rate of ENL in the 
regimen containing daily rifampicin for 9 months than in the standard WHO regimen. Thomas et al. gave rifampicin for three months only; Singh et al. gave it for 21 days, before reverting to WHO-MDT.

Motor and sensory impairments themselves have not been widely studied in relation to the impact of MDT. However, several researchers have investigated lagophthalmos. This motor impairment prevents normal eye closing and predisposes to corneal damage and loss of visual acuity, and may account for a large proportion of leprosy-related potentially blinding disease $\left(35 \%\right.$ in one study $\left.{ }^{38}\right)$.

Lagophthalmos occurred in $3.7 \%$ of the 678 patients surveyed by Waddell \& Saunderson; ${ }^{39}$ no link was found with type of treatment (monotherapy or MDT). In some cases, the lagophthalmos improved during chemotherapy. In a survey of $640 \mathrm{MB}$ patients, Courtright et al. ${ }^{38}$ found lagophthalmos in $3.8 \%$ of newly-diagnosed cases and in $10.2 \%$ of patients previously on DDS monotherapy. Good compliance with MDT diminished the risk (to $3 \%$ ) and poor compliance increased the risk (to 50\%). However, others ${ }^{40}$ claim that the risk of lagophthalmos is raised in the first 6 months of MDT (presumably due to TIRs).

Plantar ulcers, the result of sensory impairment, were studied by Mane et al. ${ }^{41}$ Ulcers were prevented by MDT, but not in patients who already had a sensory impairment at the start of therapy. For these, disability is best prevented by basic preventive measures such as protective shoes which are attractive enough for patients to wear. ${ }^{6,42}$ MDT usually limits the further development of anaesthesia; but it does not always restore sensation which has already been lost.

\section{SPECIFIC DEFORMITIES}

Specific deformities occur in patients with lepromatous (LL and BL) leprosy. Some specific impairments are caused simply by local proliferation of bacteria, while others are caused by Type 2 or ENL reactions.

Iritis is an example of a localised infection which may result in a specific impairment, and eventually blindness. The best data on MDT and iritis comes from a prolonged follow-up study of 678 patients in Kasese District, Uganda. ${ }^{39}$ Twelve per cent of patients surveyed had iritis, of whom $33 \%$ had visual loss in one or both eyes. Iritis was the primary leprosy-related cause of visual loss. The risk of iritis was not significantly greater in patients who received rifampicin late or not at all, compared to those who received it within a year after diagnosis (adjusted odds ratio $=1 \cdot 8,95 \%$ confidence intervals 0.88-3.9). MDT was not always immediately successful — four patients still suffered from iritis after 2-11 years of rifampicin. Iritis need not cause damage if treated early; the improved prognosis in recent years may result from improved overall management and earlier presentation, rather than MDT alone.

Nasal deformities are prevented by prompt chemotherapy, according to Srinivasan. ${ }^{10}$ Within a few months of starting treatment, bacilli are cleared, mucosal ulcers heal and granulomas resolve. Some disfigurement may persist and require plastic surgery. Unfortunately, there is little published work comparing the effect of MDT with that of monotherapy on the incidence of nasal damage. Since it is caused by bacterial proliferation, any antileprosy chemotherapy would be expected to help.

Arthritis may be caused by localized proliferation of bacteria in the joints, or an immune mediated reaction against synovium. In a survey of 66 patients in an Egyptian leprosy colony, Atkin et al. ${ }^{28}$ found $20(30 \%)$ had an inflammatory symmetrical peripheral polyarthritis. 11 of these patients $(55 \%)$ showed presence of bone erosion on radiography. All of the patients had 
pain on active and passive movements of the joints, which may have been disabling. Treatment with MDT led to slow resolution of the arthritis and associated morning stiffness and joint pains. In some patients, the onset of arthritis coincided with noncompliance. Unfortunately the arthritis never resolved completely, although acute exacerbations became less frequent and less severe on MDT. Some patients had permanent structural deformities. However Singh and Kaur, in a study of 60 patients in India, found no evidence of bone erosion, and joint symptoms resolved completely in most patients after one year of MDT. ${ }^{13}$

In summary, MDT largely prevents the development of new impairments caused by bacterial proliferation. Rifampicin is very effective at killing bacteria. But it may precipitate damaging immune reactions, probably due to the release of bacterial antigens. Clofazimine, through its anti-inflammatory effect, may help to prevent Type II reactions.

\section{The preventive impact of multidrug therapy on leprosy disabilities}

Apart from neuritis, the most important drug-related risk factor for the development of impairments and disabilities is the duration of active disease. The impact of MDT on this will be reviewed, firstly for paucibacillary, then for multibacillary patients. Then it will be considered whether MDT can improve the 'disability scores' of patients.

\section{PAUCIBACILLARY PATIENTS}

In paucibacillary leprosy, dapsone monotherapy was prescribed for 3-5 years and the average time to reach inactivity was $15 \pm 8.6$ months. ${ }^{44}$ Table 3 shows the percentage of patients whose lesions become inactive after 6,12 and 24 months, under different PB drug regimens. While definitions of inactivity vary from study to study, large differences between studies probably indicate true differences, and comparisons within studies are valid.

Husser et al., ${ }^{43}$ comparing DDS monotherapy with two short regimens of rifampicin monotherapy, showed clearly that it takes two years before most cases become inactive. At one year, fewer DDS cases have reached inactivity than rifampicin cases. In comparison, Bhate $e t ~ a l .{ }^{44}$ found that the majority of cases treated with two different MDT regimens became inactive within one year (average time to reach inactivity is $6.95 \pm 2.13$ months for I and $8 \cdot 21 \pm 2 \cdot 84$ months in group II). Orege et al. ${ }^{14}$ also found that most patients on the WHO regimen reached inactivity by 8 months. The modified MDT regimen-two large doses of rifampicin at an interval of three months-produced inactivity within six months. BecxBleumink $^{32}$ found that after 6 months on WHO-MDT, 114 (30.3\%) of 963 patients still had active skin lesions. Treatment was stopped according to the protocol and the skin lesions became inactive within two years in all except one of the 114 patients. The single-dose MDT regimens studied by Pattyn et al. ${ }^{45,46}$ potentially convenient and inexpensive, show a much slower progression to inactivity. The MDT regimen recommended by WHO dramatically reduced the duration of active disease in most paucibacillary patients; some other regimens may have an even greater impact. Thus MDT has prevented the development of impairments and disability in many PB patients.

MULTIBACILLARY PATIENTS

Curtailing the duration of active disease is especially important in MB leprosy, as nerve 
Table 3. Randomized-controlled trials of MDT for PB leprosy; \% of patients with all lesions inactive at 6 months, 1 year and 2 years

\begin{tabular}{|c|c|c|c|c|c|}
\hline Ref & $\mathrm{N}$ & Treatment regimen & $6 \mathrm{~m}$ & $1 \mathrm{yr}$ & $2 \mathrm{yr}$ \\
\hline 43 & $\begin{array}{l}24 \\
29 \\
22\end{array}$ & $\begin{array}{l}\text { A: } \text { DDS } 100 \mathrm{mg} \text { od, } 3 \mathrm{yr} \\
\text { B: } \\
\text { C: }\end{array}$ & $\begin{array}{l}\text { N/A } \\
\text { N/A } \\
\text { N/A }\end{array}$ & $\begin{array}{r}0-33 \\
28-57 \\
37-62\end{array}$ & $\begin{array}{l}66-91^{*} \\
51-86^{*} \\
77-95^{*}\end{array}$ \\
\hline 44 & $\begin{array}{l}40 \\
40\end{array}$ & $\begin{array}{ll}\text { A: } & \text { RMP } 600 \mathrm{mg} 1 / \mathrm{m}, 6 \mathrm{~m} \\
& \text { DDS } 100 \mathrm{mg} \text { od, } 1 \frac{1 / 2 \mathrm{yr}}{} \\
\text { B: } & \text { RMP } 600 \mathrm{mg} 1 / \mathrm{m}, 6 \mathrm{~m} \\
& \text { CLO } 100 \mathrm{mg} 1 / 2 \mathrm{~d}, 6 \mathrm{~m} \\
& \text { DDS } 100 \mathrm{mg} \text { od, } 11 \frac{1}{2} \mathrm{yr}\end{array}$ & $40 \cdot 0$ & $92 \cdot 5$ & N/A \\
\hline 14 & $\begin{array}{l}64 \\
63\end{array}$ & $\begin{array}{ll}\text { A: } & \text { WHO-PB-MDT } \\
\text { B: } & \text { RMP } 1500 \mathrm{mg} 1 / 3 \mathrm{~m}, \\
& \text { DDS } 100 \mathrm{mg} \text { od, } 6 \mathrm{~m}\end{array}$ & $\begin{array}{l}63 \cdot 3 \\
82 \cdot 3\end{array}$ & $\begin{array}{l}83.0 \\
88 \cdot 1 \\
\text { (at } 8 \mathrm{~m})\end{array}$ & $\begin{array}{l}\text { N/A } \\
\text { N/A }\end{array}$ \\
\hline 45 & 247 & $\begin{array}{l}\text { A: } \text { RMP } 1500 \mathrm{mg}, 1 \mathrm{x}, \\
\text { DDS } 100 \mathrm{mg} \text { od, } 1 \mathrm{yr} \\
\text { U: } \\
\text { RMP } 40 \mathrm{mg} / \mathrm{kg}, 1 \mathrm{x}\end{array}$ & N/A & $12-22$ & $56-67 \dagger$ \\
\hline 46 & $\begin{array}{l}223 \\
212\end{array}$ & $\begin{array}{l}\text { C2: RMP } 40 \mathrm{mg} / \mathrm{kg}, 1 \mathrm{x} \\
\text { CLO } 1200 \mathrm{mg}, 1 \mathrm{x} \\
\text { C4: RMP } 40 \mathrm{mg} / \mathrm{kg}, 1 \mathrm{x} \\
\text { CLO } 100 \mathrm{mg}, 1 \mathrm{x} \\
\text { DDS } 100 \mathrm{mg}, 1 \mathrm{x} \\
\text { ETH } 500 \mathrm{mg}, 1 \mathrm{x}\end{array}$ & N/A & N/A & $66 \cdot 8-73 \cdot 5 \ddagger$ \\
\hline
\end{tabular}

Abbreviations: see Table 1. 1/2d, once every two days.

N/A, not available, i.e. not quoted in the paper.

* Range from worst hypothesis (regressive lesions counted as uncured) to best hypothesis (regressive lesions counted as cured).

$\dagger$ Range across different patient groups, according to number of skin lesions and bacteriological index ( 0 or 1$)$.

$\ddagger 95 \%$ confidence intervals.

damage and paralysis occur only late in the course of the disease, ${ }^{12}$ and the risk is much greater than in PB leprosy. ${ }^{39}$ Yet duration of active disease is much more difficult to assess in $\mathrm{MB}$ than in PB patients.

The mouse footpad test involves inoculating mice with $10^{4}$ Mycobacterium leprae from the patient, and checking for replication. If the test is negative, it simply implies that there are fewer than one viable organism per $10^{4}$ inoculated. ${ }^{47}$ There may still be some undetected 'persisters' in the patient, which could cause a relapse. Nevertheless, this test is useful in the initial stages of therapy to determine the speed of killing. An untreated MB patient may harbour $10^{11} \mathrm{M}$. leprae, of which $10^{10}$ may be viable. This technique has shown that $M$. leprae from the lesions of $\mathrm{MB}$ patients no longer infect mice after different periods according to the drug regimen (Table 4). Single-dose rifampicin $(600-1500 \mathrm{mg})$ is clearly the best bactericidal treatment; there is no evidence in these studies to suggest that other drugs potentiate its effect in killing M. leprae.

Clinical evaluation of the duration of active disease is also important. The single randomized-controlled trial comparing DDS monotherapy with $\mathrm{MDT}^{17}$ found that $20 \%$ of patients treated by monotherapy (group A) still had clinically 'progressive' disease at 6 months, compared to $0 \%$ of those on MDT (Figure 1). The three groups were broadly comparable, but more of group A had nerve motor function impairment (26\% compared to 
Table 4. Period after which $M$. leprae from MB patients are no longer infective to normal mice m $^{4,48}$

\begin{tabular}{lcl}
\hline Regimen & Period & Ref \\
\hline DDS 50-100 mg od & $100 \mathrm{~d}$ & 47 \\
CLO 100-200 mg od, or 100 mg 3/wk & $150 \mathrm{~d}$ & 16,47 \\
RMP 600-1500 mg 1x & $7 \mathrm{~d}$ & 47,48 \\
CLT, 500 mg od & $28 \mathrm{~d}$ & 20 \\
MIN, 100-200 mg od & $56 \mathrm{~d}$ & 19,20 \\
OFL 400-800 mg od & $28 \mathrm{~d}$ & 18,49 \\
PEF 800 mg od & $56 \mathrm{~d}$ & 49 \\
& & \\
\hline
\end{tabular}

Abbreviations: see Table 1 .

$18 \%$ in $\mathrm{B}$ and $16 \%$ in $\mathrm{C}$ ) and thickening of nerves (31\%, compared to $21 \%$ in $\mathrm{B}$ and $19 \%$ in C). These may indicate an advantage of MDT, or more active disease at the outset of treatment in those given the DDS monotherapy. However, given the above data for the bactericidal impact of rifampicin, the first explanation is the most likely.

\section{DISABILITY SCORES}

The ideal test of the impact of MDT on disabilities in different individuals would be to monitor their 'disability scores' before and after treatment. Unfortunately the few studies that have done this do not use a common scoring system. WHO scales do not differentiate between deformity and disability, and significant changes can occur in the extent of disability without a change in the disability grades. ${ }^{11}$

Smith $^{50}$ notes that those with impairment naturally tend to deteriorate. Chemotherapy may help to prevent this deterioration. Smith \& Parkhe ${ }^{51}$ failed to find a change in the mean disability index of 153 patients after four years of DDS monotherapy. Pönnighaus \& Boerrigter $^{23}$ found that MB patients receiving only 18 doses of WHO-MDT had a higher risk of developing disabilities than those receiving 30 doses. Groenen et al., ${ }^{15}$ in a prospective study of $335 \mathrm{~PB}$ and $280 \mathrm{MB}$ patients taking various regimens (MDT, RMP monotherapy) found that deformity scores remained unchanged in $95 \%$ of patients, deteriorated in $3 \%$ and improved in $2 \%$. Richardus et al $^{52}$ obtained similar results: $1.6 \%$ of previously normal patients developed nerve function impairment and $1.3 \%$ with impairment recovered by the end of treatment; corresponding figures for $\mathrm{MB}$ patients were $7.9 \%$ and $4.0 \%$ respectively.

\section{DISABILITY RATES}

It is notoriously difficult to measure the level of disabilities in different populations if one adheres to the strict definition of disability as 'any restriction or lack of ability to perform an activity in the manner as within the range considered normal for a human being' ${ }^{50}$ It has been argued that any impairments should be taken into account because 'Grade I disabilities' may deteriorate into 'Grade II disabilities' unless preventive action is taken. ${ }^{53}$ Nevertheless most studies take account only of 'Grade II' disabilities.

The prevalence, or proportion of all leprosy patients with disabilities (grade II) at a single point in time, is given by several surveys. It varies from $60 \%$ in Nigeria in $1988^{54}$ to $12 \%$ in 


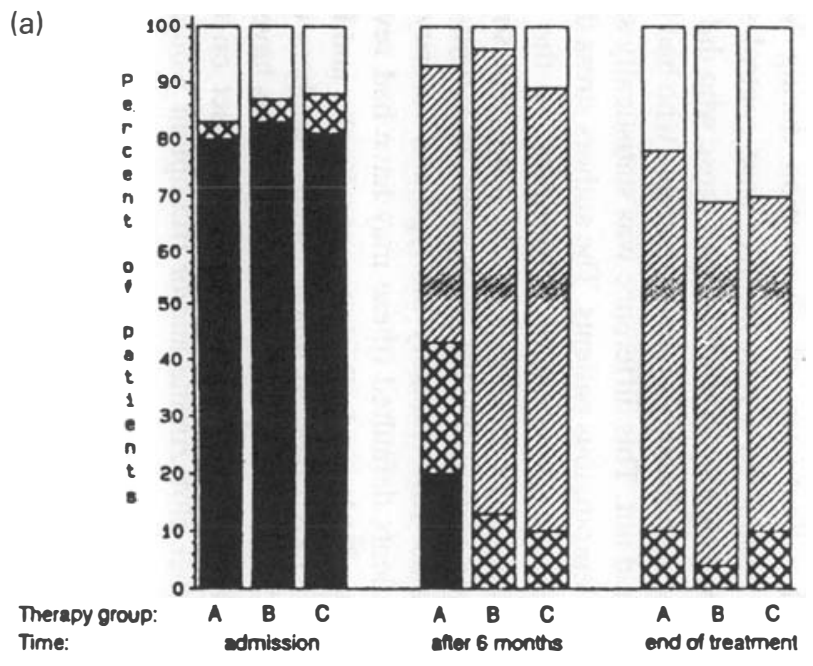

Clinical status of 130 patients with lepromatous leprosy. . progressive; , stable; regressive; $\square$, missing.

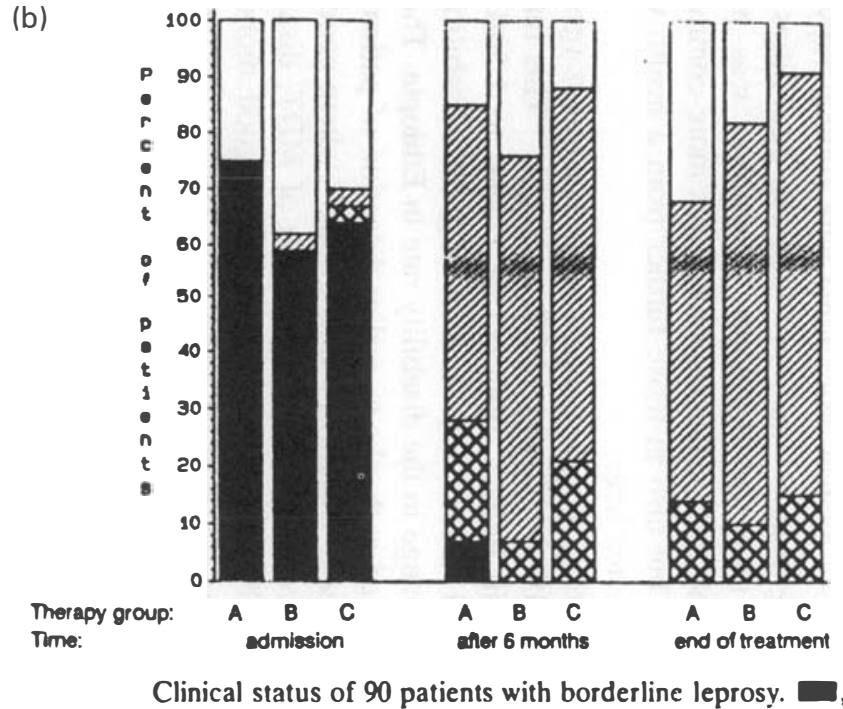

progressive; , stable; 
India in $1989 .{ }^{53}$ Smith \& Parkhe ${ }^{51}$ demonstrated a decline in the proportion of patients with disabilities in spite of an increase in the number of cases of leprosy from 1979 to 1983 in India. They claimed that the leprosy control programme with monotherapy had slowed the deterioration in those with existing disability and prevented new disabilities. However, early detection of new cases before they had developed disabilities was probably equally important. Courtright et al. ${ }^{55}$ found that ocular morbidity was more common in those who did not comply with their MDT, but also in those further from a health worker or health centre, who would have been detected later.

The disability rate, or proportion of new patients with disabilities (grade II) has been measured as $10.9 \%$ in China in $1982-3^{56}$ and $12.7 \%$ in Nepal. ${ }^{57}$ This rate has decreased following introduction of MDT in India, ${ }^{58}$ from $6 \cdot 15 \%$ (1984) to $1.50 \%$ (1987), and in Ethiopia, ${ }^{32}$ from $20.6 \%$ (1984) to $13.9 \%$ (1989). However if grade I disabilities are also taken into account, there has been no change in the disability rate in Ethiopia. That the proportion with severe disabilities has declined is thanks to earlier detection of patients rather than an effect of MDT per $s e .^{32}$ In Thailand, ${ }^{59}$ Malaŵi $^{60}$ and China, ${ }^{61}$ where good leprosy control programmes were already in place before the introduction of MDT, disability rates have remained stable. Yet in French Polynesia, which also had a good monotherapy control programme, the disability rate was stable at an average of $31.5 \%$ until the introduction of MDT when it dropped to an average of $11 \cdot 7 \% .^{62}$ This may have been thanks to household contact training, leading to better detection in children below the age of 15 . The risk of disability is lower for younger patients. ${ }^{63}$ Conversely, disability rates have increased in Bhutan despite the introduction of MDT, because fewer mass surveys are being done to detect patients early; these have become uneconomical as the prevalence of leprosy has fallen. ${ }^{64}$

The incidence of impairment during treatment is fairly low: $11.1 \%$ of patients receiving DDS for 5 years in India; ${ }^{65} 2 \%$ of patients after 2-7 years of DDS chemotherapy in Trinidad and Tobago; ${ }^{66}$ and 0.7 per 1000 patient-years of observation during MDT in India. ${ }^{67}$ However, Radhakrishna \& Nair ${ }^{65}$ conducted a retrospective case-control study of patients on DDS monotherapy who developed leprosy disabilities and those who did not. They found that the incidence of disabilities was significantly higher in patients who had been taking their drugs regularly than in those who had not. This difference was statistically significant for PB and borderline patients, but not for lepromatous patients. The authors stress that they assessed regularity of drug-taking before the development of deformities; so the result is not an artefact due to deformed patients being more motivated to take drugs. The study suggests that regular DDS increases the risk of impairments for $\mathrm{PB}$ and borderline patients, possibly due to the increased risk of Type I reactions. Unfortunately the type and severity of impairments were not recorded, and $30 \%$ of patients defaulted (these may have had severe disabilities). This finding was replicated by Gupte, ${ }^{68}$ also in India, but not by Keeler and Ryan in Trinidad and Tobago. ${ }^{66}$ However the latter study involved much smaller numbers of patients $(529$, compared to 5746 in study 65 and 2608 in study 68). No similar studies have been conducted for MDT, so it is not clear whether it would have the same impact on the incidence of disabilities as DDS alone, or whether clofazimine and/or rifampicin would protect against development of deformities.

MDT itself cannot affect the disability rate, which declines in response to earlier case detection. The incidence of impairments during treatment may be lower with MDT than with monotherapy, but this has yet to be proven definitively. It would be especially interesting to know whether those who take their MDT regularly are more or less likely to develop deformities than those who take it less regularly. 


\section{Discussion}

MDT has a number of advantages over DDS monotherapy, which it has superceded. As well as its preventive and epidemiological impacts described above, MDT may have a number of important indirect effects. Compliance is improved, ${ }^{69,70}$ partly because the regimens are shorter. Cost is also reduced. ${ }^{69}$ Self-reporting may increase when patients know there is an effective treatment; ${ }^{71}$ this has been observed in Bhutan, ${ }^{64}$ although not in Malaw $i^{60}$ or in all areas of China. ${ }^{61}$ The caseload of leprosy workers decreases dramatically as patients are released from control much faster; ${ }^{72-75}$ this releases time for surveillance work, prevention and treatment of disabilities. ${ }^{53}$ The more frequent (monthly) contact between health workers and patients, for supervised administration of rifampicin, provides more opportunities for health education and disability prevention. ${ }^{74}$ The greater efficacy of MDT may have motivated health workers to improve drug coverage and routine assistance to patients with leprosy, ${ }^{76}$ stimulating better compliance, and setting in motion a virtuous circle.

Yet MDT also has its disadvantages. It does not eliminate microbial antigens from nerves, which may perpetuate neuritis and cause further impairments long after the patient is 'cured'.77 For example, corneal sensation sometimes continues to decrease long after the completion of MDT, ${ }^{78}$ and this leads to loss of vision. Second, allocation of patients to the PBor MB regimen is not always easy. ${ }^{32,76}$ The higher cost of MDT in the short term ${ }^{79}$ may be prohibitive in impoverished areas where leprosy is commonest. It would be tragic if statistics of declining global prevalence were misinterpreted to justify reduced funding for the treatment of leprosy. ${ }^{80}$

The problem of leprosy disabilities cannot be solved by MDT alone. Other approaches are also necessary, both to prevent disabilities and to help those already afflicted. These have often been neglected while the WHO has vigorously promoted MDT. Most important for prevention are early case-finding and adequate treatment of reactions, and also improvements in infrastructure and socioeconomic conditions. Good housing and schooling both decrease the risk of leprosy. ${ }^{81}$

Those who are already disabled need re-ablement, disability prevention and rehabilitation. ${ }^{4}$ Programmes to prevent and treat disabilities have the added bonus of improving compliance with MDT. ${ }^{74}$ Although MDT improves the recovery of lost function ( $50 \%$, compared to $20 \%$ with monotherapy in Malawi $i^{82}$ ), it cannot cure many deformities. $8.3 \%$ of leprosy disabilities could be reversed by surgery, health education and physiotherapy. ${ }^{63}$ Health education is important to prevent new disabilities from developing when the patient has lost sensation and/or movement in a part of their body. New habits for living and working must be learnt and harmful old habits discarded. This involves behaving differently from others, possibly provoking ridicule, so the support of family and neighbours must be enlisted. ${ }^{4}$ Last but not least, rehabilitation is necessary to re-integrate disabled patients into society and to help them lead as normal a life as possible. Although some aid agencies are doing rehabilitation work it is relatively expensive: it costs $£ 44$ to establish a vegetable business, and $£ 141$ to train a tailor. ${ }^{83}$ Therefore it has been argued that the money would be better spent on improving MDT coverage to prevent new disabilities from occurring. ${ }^{84}$

\section{Conclusion}

MDT has had an impact on leprosy disabilities, especially by stopping active disease and so 
preventing the development of disabilities in the long term. This benefit outweighs the shortterm cost of increased risk of immune reactions which may result in impairment and disability. Not surprisingly, MDT has had no impact on already existent disabilities, nor on the incidence of disabilities in untreated patients. These last two problems must be tackled by other means. Although the number of registered cases of leprosy has declined dramatically, many 'cured' people still suffer from disabilities and need re-ablement, health education and rehabilitation. These must be promoted in conjunction with MDT to tackle effectively the age-old problem of leprosy disabilities.

\section{Acknowledgment}

I would like to thank all those at LEPRA who helped to run this essay competition, and especially Dr D.N.J. Lockwood for giving so much of her time to help me edit my essay. I would also like to thank Dr and Mrs C.P.W. Willcox for their constant encouragement and support.

\section{References}

1 Noordeen SK. Elimination of leprosy as a public health problem: progress and prospects. Bull WHO, 1995; 73: 1-6.

2 Kaur H, Ramesh V. Social problems of women leprosy patients- a study conducted at 2 urban leprosy centres in Delhi. Lepr Rev, 1994; 65: 361-375.

3 Kopparty SNM. Problems, acceptance and social inequality: a study of the deformed leprosy patients and their families. Lepr Rev, 1995; 6: 239-249.

4 Srinivasan H. Not by Chemotherapy alone. Int J Lepr, 1994; 62: 404-411.

5 Jacobson RR. Treatment of Leprosy. In: Hastings, RC (Ed). Leprosy. London: Churchill Livingstone, 1994.

6 Becx-Bleumink M, Berhe D, Mannetje WT. The management of nerve damage in the leprosy control services. Lepr Rev, 1990; 61: 1-11.

7 Job CK. Nerve damage in leprosy. Int J Lepr, 1989; 57: 532-539.

${ }^{8}$ Hamilton J. Deformity prevention in the field: a systematic approach. Lepr Rev, 1983; 54: 229-37.

9 Magora A, Sheskin J, Sagher F, Gonen B. The condition of the peripheral nerve in leprosy under various forms of treatment. Int J Lepr, 1971; 39: 639-52.

10 Srinivasan H. Disability, deformity and rehabilitation. In: Hastings, RC (Ed). Leprosy. London: Churchill Livingstone, 1994.

11 Lienhardt C, Fine PEM. Type 1 reaction, neuritis and disability in leprosy. What is the current epidemiological situation? Lepr Rev, 1994; 65: 9-33.

12 Parkes M. The mechanism of nerve damage in leprosy. In: Ryan TJ, McDougall AC (Eds). Essays on Leprosy. Oxford: Alden Press, 1988.

13 Singh I, Kaur S, Khandelwal N, Kaur I, Deodhar SD. Arthritis in leprosy: clinical, laboratory and radiological assessments. Int J Lepr, 1994; 62: 428-33.

14 Orege PA, Obura M, Okelo C, Okuku P, Makokha S, Nyawalo J. Multidrug therapy for treatment of paucibacillary leprosy in western Kenya-preliminary communications. East Afr Med J, 1990; 67: 632-9.

15 Groenen G, Janssens L, Kayembe T, Nollet E, Coussens L, Pattyn SR. Prospective study on the relationship betweem intensive bactericidal therapy and leprosy reactions. Int J Lepr, 1986; 54: 236-44.

16 Jamet P, Traore I, Husser JA, Ji B. Short-term trial of clofazimine in previously untreated lepromatous leprosy. Int J Lepr, 1992; 60: 542-8.

17 Dietrich M, Gaus W, Kern P, Meyers WM. An International Randomised Study with long-term follow-up of single versus combination chemotherapy of multibacillary leprosy. Antimicrob Agents Chemother, 1994; 38: 2249-2257.

18 Ji B, Perani EG, Petinom C, N'deli L, Grosset JH. Clinical trial of ofloxacin alone and in combination with dapsone plus clofazimine for treatment of lepromatous leprosy. Antimicrob Agents Chemother, 1994; 38: 662-7.

19 Fajardo TT, Villahermosa LG, dela Cruz EC, Abalos RM, Franzblau SG, Wlash GP. Minocycline in lepromatous leprosy. Int J Lepr, 1995; 63: 8-17.

$20 \mathrm{Ji}$ B, Jamet P, Perani EG, Bobin P, Grosset JH. Powerful bactericidal activities of clarithromycin and minocycline against Mycobacterium leprae in lepromatous leprosy. J Infect Dis, 1993; 168: 188-90. 
21 Thomas A, Balakrishnan A, Nagarajan M et al. Controlled clinical trial of two multidrug regimens with and without rifampicin in highly bacilliferous BL/LL South Indian patients: a five-year report. Int J Lepr, 1990; 58: 273-9.

22 Singh RP, Tiwari VD, Chattopadhyay SP. Comparative study of short term results in two multidrug regimens in multibacillary leprosy. Ind J Lepr, 1993; 65: 173-180.

23 Pönnighaus JM, Boerrigter G. Are 18 doses of WHO/MDT sufficient for multibacillary leprosy; Results of a trial in Malawi. Int J Lepr, 1995; 63: 1-7.

24 Zaheer SA, Mukherjee R, Ramkumar B et al. Combined multidrug and Mycobacterium $w$ vaccine therapy in patients with multibacillary leprosy. J Infect Dis, 1993; 167: 401-10.

25 Barnetson RStC, Pearson JMH, Rees RJW. Evidence for prevention of borderline leprosy reactions by dapsone. Lancet, 1976; II: 1171-2.

${ }^{26}$ Cree IA, Coghill G, Subedi AMC et al. Effects of treatment on the histopathology of leprosy. J Clin Pathol, 1995; 48: $304-7$.

27 de Almeida Pernambuco JC, Cossermelli-Messina W. Rheumatic manifestations of leprosy: clinical aspects. J Rheumatol, 1993; 20: 897-9.

28 Atkin SL, El-Ghobarey A, Kamel M, Owen JP, Dick WC. Clinical and laboratory studies of arthritis in leprosy. BMJ, 1989; 298: 1423-5.

29 Cellona RV, Fajardo TT, Kim D et al. Joint Chemotherapy trials in lepromatous leprosy conducted in Thailand, the Philippines, and Korea. Int J Lepr, 1990; 58: 1-11.

30 Jadhav VH, Patki AH, Mehta JM. Comparison of two multidrug regimens in multibacillary leprosy. Ind J Lepr, 1992; 64: 501-4.

31 Zaheer SA, Misra RS, Sharma AK et al. Immunotherapy with Mycobacterium $w$ vaccine decreases the incidence and severity of Type 2 (ENL) reactions. Lepr Rev, 1993; 64: 7-14.

32 Becx-Bleumink M. Multidrug therapy in the control of leprosy: a field study. Trop Geogr Med, 1994; 46: $109-14$.

33 Bwire R, Kawuma HJS. Hospital-based epidemiological study of reactions, Buluba Hospital, 1985-89. Lepr Rev, 1993; 64: 325-9.

34 Ridley DS, Waters MFR. Significance of variations within the lepromatous group. Lepr Rev, 1969; 40: $143-52$.

35 WHO Study Group on Chemotherapy of Leprosy. Chemotherapy of leprosy. WHO technical report series: 847. Geneva: WHO, 1994.

36 Post E, chin A lien RA, Bouman C, Naafs B, Faber WR. Lepra in Nederland in de periode 1970-1991. Ned Tijdschr Geneeskd, 1994; 138: 1960-3.

37 Burte NP, Chandorkar AG, Muley MP, Balsara JJ, Bulakh PM. Clofazimine in Lepra (ENL) reactions: one year clinical trial. Lepr India, 1983; 55: 265-77.

${ }^{37 a}$ Helmy HS, Pearson JMH, Waters MFR. Treatment of moderately severe erythema nodosum leprosum with clofazimine-a controlled trial. Lepr Rev, 1972; 42: 167-77.

38 Courtright P, Lewallen S, Li H, Hu L, Yang J. Lagophthalmos in a multibacillary population under multidrug therapy in the People's Republic of China. Lepr Rev, 1995; 66: 214-9.

39 Wadell KM, Saunderson PR. Is leprosy blindness avoidable? Br J Ophthalmol, 1995; 79: 250-6.

40 Daniel E, Chacko S, Arunthathi S. Lid retraction as an indicator of lagophthalmos in leprosy: a preliminary report. Int J Lepr, 1994; 62: 436-7.

41 Mane I, Grauwin MY, Cartel JL. Fréquence d'apparition de maux perforants plantaires chez des malades hanseniens en fonction du traitement par disulfone seule ou polychimiothérapie. Acta Leprol, 1995; 9: 127-31.

42 Saunderson PR, Seboka G. Protective footwear for leprosy patients with sole sensory loss or ulceration of the foot. Lepr Rev, 1995; 66: 257-63.

43 Husser JA, Baquillon G, Pattyn SR. Comparaison de trois régimes thérapeutiques dans la lèpre paucibacillaire: Note préliminaire. Acta Leprol, 1986; IV: 447-52.

44 Bhate RD, Gupta CM, Chattopadhay SP, Singh IP. Experience with multidrug therapy in paucibacillary leprosy. Ind J Lepr, 1986; 58: 244-250.

45 Pattyn SR, Groenen G, Janssens L et al. A controlled therapeutic trial in paucibacillary leprosy comparing a single dose of rifampicin with a single dose of rifampicin followed by one year of daily dapsone. Lepr Rev, 1991; 62: 179-85.

46 Pattyn SR, Ghys P, Janssens L et al. A randomized clinical trial of two single-dose treatments for paucibacillary leprosy. Lepr Rev, 1994; 65: 45-57.

47 Levy L. THELEP controlled clinical trials in lepromatous leprosy. Lepr Rev, 1983; 54: 167-76.

48 Husser JA. Activity of two doses of rifampin against Mycobacterium leprae. Int J Lepr, 1994; 62: 359-64.

49 Grosset JH, Ji B, Guelpa-Lauras CC, Perani EG, N'Deli LN. Clinical trial of pefloxacin and ofloxacin in the treatment of lepromatous leprosy. Int J Lepr, 1990; 58: 281-295.

50 Smith WCS. The epidemiology of disability in leprosy including risk factors. Lepr Rev, 1992; 63 (suppl): 23s-30s.

51 Smith WCS, Parkhe SM. Disability assessment as a measure of progress in leprosy control. Lepr Rev, 1986; 57: 251-9.

52 Richardus JH, Finlay KM, Croft RP, Smith WCS. Nerve function impairment in leprosy at diagnosis and at completion of MDT: a retrospective cohort study of 786 patients in Bangladesh. Lepr Rev, 1996; 67: 297-305. 
53 Revankar CR, Pawar PL, Belurkar LS, Pai RR, Ganapati R. Reduction in caseload after multidrug therapy in an urban leprosy control programme - a retrospective study in Bombay. Lepr Rev, 1991; 62: 44-48.

54 Waaldijk K. The actual leprosy situation within Katsina State, Nigeria. Lepr Rev, 1988; 59: 355-361.

55 Courtright $\mathrm{P}, \mathrm{HuL}, \mathrm{LiH}$, Lewallen S. Multidrug therapy and eye disease in leprosy: a cross-sectional study in the People's Republic of China. Int J Epidemiol, 1994; 23: 835-42.

$56 \mathrm{Li} \mathrm{H}$, Yu-Lin P, Yang W. Leprosy control in Shandong province, China, 1955-1983; Some epidemiological features. Int J Lepr, 1985; 53: 79-85.

57 Theuvenet WJ, Soares D, Baral JP et al. Mass survey of Leprosy in Lalitpur district, Nepal. Int J Lepr, 1994; 62: 256-262.

58 Chopra NK, Agarwal JS, Pandya PG. Impact of multidrug therapy on leprosy in Baroda district (Gujarat). Ind J Lepr, 1989; 61: 179-89.

59 Pirayavaraporn C, Peerapakorn S. The measurement of the epidemiological impact of multidrug therapy. Lepr Rev, 1992; 63 (supplement): 84s-92s.

60 Boerrigter G, Pönnighaus JM. Does the introduction of WHO-MDT influence trends in the incidence of leprosy?-the Malaian experience. Lepr Rev, 1993; 64: 227-235.

$61 \mathrm{Li} \mathrm{H}$, Weng X, Li T et al. Long-term effect of leprosy control in two prefectures of China, 1955-1993. Int J Lepr, 1995; 63: 213-221.

62 Cartel J-L, Spiegel A, Nguyen Ngoc L, Moulia-Pelat J-P, Martin PMV, Grosset J-H. Leprosy in French Polynesia. The possible impact of multidrug therapy on epidemiological trends. Lepr Rev, 1992; 63: 223-230.

${ }^{63}$ Smith WCS, Antin US, Patole AR. Disability in leprosy: a relevant measurement of progress in leprosy control. Lepr Rev, 1980; 51: 155-66.

64 Jakeman P, Jakeman NRP, Singay J. Trends in Leprosy in the Kingdom of Bhutan, 1982-1992. Lepr Rev, 1995; 66: $69-75$.

65 Radhakrishna S, Nair NGK. Association between regularity in Dapsone (DDS) treatment and development of deformity. Int J Lepr, 1987; 55: 425-434.

66 Keeler RF, Ryan MA. The incidence of disabilities in Hansen's disease after the commencement of chemotherapy. Lepr Rev, 1980; 51: 149-154.

67 Rao PS, Subramanian M, Subramanian G. Deformity incidence in leprosy patients treated with multidrug therapy. Ind J Lepr, 1994; 66: 449-54.

68 Gupte MD. Dapsone treatment and deformities: a retrospective study. Lepr India, 1979; 51: 218-35.

69 Becx-Bleumink M. Relapses in leprosy patients after release from dapsone monotherapy; Experience in the leprosy control program of the all Africa leprosy and rehabilitation training center (ALERT) in Ethiopia. Int $J$ Lepr, 1992; 60: 161-72.

70 Lienhardt C, Fine PEM. Controlling leprosy. BMJ, 1992; 305: 206-7.

71 Noordeen SK. Elimination of leprosy as a public health problem. Int J Lepr, 1994; 62: 278-283.

72 Day R, Lever P, Asri M. Leprosy control in 7 districts of South Sulawesi, Indonesia, 1986-91. Lepr Rev, 1992; 63: 247-254.

73 Suite M, Edinborough NB. A second report on multidrug therapy for leprosy in Trinidad and Tobago. Lepr Rev, 1989; 60: 288-299.

74 Andrade VLG, Marques AB, da Cunha LHV, Avelleira JR. Feasibility of multidrug therapy (MDT) in Hansen's disease in an urban population-Curupaiti State Hospital, Rio de Janeiro, Brazil. Int J Lepr, 1987; 55: 435-440.

75 Ekambaram V, Rao MK. Changing picture of leprosy in North Arcot District, Tamil Nadu after MDT. Ind J Lepr, 1989; 61: 31-43.

76 Martelli CMT et al. Changes in leprosy clinical pattern after multidrug therapy implementation. Int J Lepr, 1995; 63: $95-7$.

77 Antia NH. Overview of leprosy: four decades of personal observations. ILA Forum, 1995; 2(2): 6-10.

78 Daniel E. Multidrug Therapy and After: Changing Visage of Ocular Leprosy. Int J Lepr, 1994; 62: 437-9.

79 Lechat MF, Declercq EE, Misson CB, Vellut CM. Selection of MDT strategies through epidemiometric modeling. Int J Lepr, 1990; 58: 296-301.

80 Fine PEM. Reflections on the elimination of leprosy. Int J Lepr, 1992; 60: 71-80.

81 Pönnighaus JM, Fine PEM, Sterne JAC, Malema SS, Bliss L, Wilson RJ. Extended schooling and good housing conditions are associated with reduced risk of leprosy in rural Malawi. Int J Lepr, 1994; 62: 345-352.

82 Bryceson A, Pfaltzgraff RE. Leprosy. London: Churchill Livingstone, 1990.

83 The Leprosy Mission. What your gift will achieve. New Day, 1995; 355: 8.

${ }^{84}$ Crawford CL. Leprosy: is the strategy wrong? Nature, 1975; 254: 168-70. 